\title{
Life History of the Marine Isopod Cyathura polita in the Saint John River Estuary, New Brunswick: a Species at the Northern Extent of its Range
}

\author{
Sarah C. Mercer ${ }^{1}$, Glenys D. Gibson ${ }^{2}$, and Michael J. Dadswell ${ }^{3}$ \\ Department of Biology, Acadia University, Wolfville, Nova Scotia B4P 2R6 Canada \\ ${ }^{1}$ sarah_mercer9@hotmail.com \\ 2 glenys.gibson@acadiau.ca \\ ${ }^{3}$ Corresponding author. Email: mdadswell@bwr.eastlink.ca Phone: (902) 585-1161. Fax: (902) 585-1059
}

Mercer, Sarah C., Glenys D. Gibson, and Michael J. Dadswell. 2007. Life history of the Marine Isopod Cyathura polita in the Saint John River estuary, New Brunswick: A species at the northern extent of its range. Canadian Field-Naturalist 121(2): 168177.

The marine isopod, Cyathura polita, inhabits estuaries on the east coast of North America from the Gulf of Mexico to the Bay of Fundy, Canada. We studied C. polita in the Saint John estuary to test for potential differences in life history that might occur because of the northern location of the population. In the Saint John, based on our interpretation from a six-month sampling program (May-October), the population exhibits a three-year life cycle, one year longer than more southern populations, and stretching over four summers. Our study supported the occurrence of protogynic hermaphroditism. After two summers as juveniles, individuals matured as females during their third summer, then displayed sex reversal by becoming males that fall, and finally reproducing as males in their fourth summer of life before death. Mean length of $C$. polita from the Saint John was greater than individuals from more southern populations (females, $13.8 \pm 2.14 \mathrm{~mm}$; males, $16.3 \pm 2.41 \mathrm{~mm}$ ). Annual brood release occurred in late July-early August. Mean fecundity of females was 53.2 \pm 18.9 embryos per brood, which was greater than found in southern populations. Cyathura polita is rare in Canada and is known only from the Saint John and along the northern shore of the Bay of Fundy to the border of the United States.

Key Words: Isopod, Cythura politica, growth, reproductive cycle, fecundity, protogynic hermaphroditism, status, St. John River, New Brunswick.

Our knowledge of life history evolution depends on understanding intraspecific variation in life history traits, such as those correlated with latitude. Cyathura polita (Stimpson, 1855) is a benthic isopod that occurs in estuaries along the Atlantic coast of North America from the Gulf of Mexico to the Bay of Fundy, Canada (Burbanck et al. 1979), and is an appropriate model for such a study. Latitudinal variations in life history traits have been demonstrated for $C$. polita populations from Florida to Cape Cod, and include adult size and life span (Burbanck and Burbanck 1979). Latitudinal differences in life history traits have been described in the common cyathuran of the eastern Atlantic, Cyathura carinata, among populations from Portugal to Sweden (Bamber 1985; Olafsson and Persson 1986; Marques et al. 1994; Cruz et al. 2003). In the present study, we investigated life history characteristics of $C$. polita for its northernmost known population in the Saint John River estuary, New Brunswick.

Cyathurans are interstitial isopods that live in burrows and feed on detritus and algae in the sediment (Burbanck 1959). They are eurytopic animals, tolerating wide fluctuations in conditions such as temperature and salinity, an adaptation suitable to estuaries. They are also an important indicator organism for healthy estuarine ecotones because they are usually present only in unpolluted waters (Burbanck and Burbanck 1979). Cyathurans in general do not swim as adults nor do they have a pelagic larval stage, resulting in populations that are relatively immobile, sessile and disjunct. According to Burbanck (1959, 1962a, b), C. polita inhabits estuaries where fresh and salt water mix over stable sediment containing gravel, silt and detritus. They are obligatory aquatic animals and cannot withstand long periods of dryness (Burbanck and Burbanck 1979). Often $C$. polita are located in transitional zones where cattails (Typha) and salt marsh grasses (Spartina) meet along the shoreline (Burbanck 1962b). They are an important food for ducks and fishes (Burbanck and Burbanck 1979; Dadswell 1979).

The life cycle of $C$. polita varies with latitude (Burbanck and Burbanck 1979). In southern populations, the life cycle duration is generally one year. In Florida, young are released from May to October, and grow over the winter until they mature and produce young the following spring and summer. Most southern cyathurans die at the end of their second summer (Kruczynski and Subrahmanyam 1978). In more northern locations, such as Cape Cod, the young are released in early summer (late June or early July), grow rapidly in the fall, and produce young the following year. In these populations some cyathurans die at the end of their second summer while others may survive a second winter and reproduce the following year, often exhibiting protogynic hermaphroditism (Burbanck and Burbanck 1979). 
Cyathuran females carry their embryos in a ventral marsupium made of overlapping pairs of oostegites (Stromberg 1972). The embryos develop in the marsupium until they hatch from a vitelline membrane and are released into the environment as juveniles. This method of reproduction permits detailed study of fecundity and development in cyathurans, making the species an excellent model for life history studies.

Cyathura polita has been studied extensively in the United States, particularly in the southern states (Burbanck and Burbanck 1979). The Saint John River estuary and along the north Bay of Fundy shore to the United States border are so far the only known occurrences of $C$. polita in Canada, and these populations are located at the northern extent of its range (Burbanck et al. 1979, Atlantic Reference Center, St. Andrews, New Brunswick). We investigated the life history of C. polita in the Saint John River estuary, and compared these data to published observations to explore the hypothesis that northern cyathurans would exhibit differences in life history relative to those at southern latitudes. We suspected that, with probable slower growth in this population, body size of adults would be greater because of delayed maturity and the larger females would carry more embryos. Also, since this is one of the few Canadian populations of an organism which has poor powers of dispersal caused by its non-swimming life style and a brooding reproductive method, it may be important to characterize its life history for future reference under the Species at Risk Act. Finally, the Saint John River estuary is a unique habitat in Canada containing elements of Virginian, coastal marine ecosystems in the summer-warm shallows (Bousfield 1962; Burbanck et al. 1979; Dadswell 1979), boreal, marine species in its deep, fjord-like basins (Trites 1960; Carter and Dadswell 1983) along with the wide range of freshwater, diadromous, and marine species typically found in Atlantic Canada (Rogers 1936; Bousfield 1962; Gorham 1965; Gillis 1974).

\section{Study Area and Methods}

Samples of Cyathura polita were collected from the subtidal shore of the lower Saint John River estuary from four stations: Bell Point, Westfield Beach, Summerville and Millidgeville (Figure 1). This region is the junction between the Bay of Fundy and the Saint John River and both estuary outflow and tidal inflow are inhibited by a sill at the Reversing Falls. As a result, there are large fluctuations in salinity because of freshwater discharge, and inside the estuary tidal range is reduced to $0.5 \mathrm{~m}$ and summer surface temperatures are higher than in the Bay of Fundy (Metcalfe et al. 1976). The Saint John River has a salt wedge estuary combined with deep, fjord-lake basins, and surface salinities at the seaward end fluctuate throughout the year, falling to $0 \%$ during spring freshet and increasing to $20 \%$ during low freshwater flow (Metcalfe et al. 1976).
Samples were collected approximately bi-weekly, usually at low tide, from 29 May to 27 August 2004, with an additional collection on 10 October 2004. Samples of $C$. polita were collected randomly by removing the surface substrate from subtidal sites in water depths of 20 to $150 \mathrm{~cm}$. Substrate was collected with a shovel, and sieved through $1 \mathrm{~mm}$ or $0.25 \mathrm{~mm}$ mesh. The smaller mesh size was used to capture juveniles too small to be retained by the larger mesh. Approximately 30 adults and 30 juveniles, if possible, were collected from each location during a sampling effort. Individuals were fixed on the day collected in $10 \%$ formalin buffered in sea water and transferred to $70 \%$ isopropyl alcohol within three days. On each collection date at each station, the water temperature at $0.5 \mathrm{~m}$ depth was measured using a mercury thermometer, and a 1L sample of surface water was collected for salinity measurements later in the laboratory. Sediment samples from each station (1L) were collected on 17 July 2004.

Salinity was measured using an YSI 30 Salinity meter, after calibration with a mercury thermometer. Sediment samples were analyzed for proportions of gravel, sand, and silt, using a sieve series where gravel was $<38.1 \mathrm{~mm}$, sand $<2.0 \mathrm{~mm}$, and silt $<63 \mu \mathrm{m}$ (Miall 2000).

Within a few days of capture, the total length of all individuals was measured to the nearest $\mathrm{mm}$ from the base of the antennae to the tip of the telson. Measuring the total body length was preferred to estimating size from prosomal length (Bamber 1985), for comparison with other literature on C. polita. Males were distinguishable by the presence of an appendix masculina on the second pleopod; females could be accurately distinguished only when with oostegites forming a brood pouch or marsupium (Figure 2). Individuals without these sexual dimorphisms were considered to be juveniles.

All gravid females with intact marsupia were analyzed for number and size of embryos. Embryos were removed from marsupia and classified into four stages of development based on electron microscopy (Mercer et al., in press): Class 1 embryos were round and contained within two membranes, the chorion and vitelline membranes; Class 2 embryos were elongated and showed differentiation of the three body regions (head, thorax, abdomen), but lacked differentiation of the appendages; Class 3 embryos were still housed within the vitelline membrane, but had considerable differentiation of appendages and head; and Class 4 embryos were hatched from the vitelline membrane and had well-differentiated appendages. Embryos were measured with a compound microscope to the nearest $17 \mu \mathrm{m}$.

Adults and embryos were prepared for scanning electron microscopy (SEM) with primary fixation in $2.5 \%$ glutaraldehyde $(1 \mathrm{hr})$, followed by a post-fixation in $1 \%$ osmium tetraoxide $(4 \mathrm{hrs}$, both fixes in $0.1 \mathrm{M}$ 


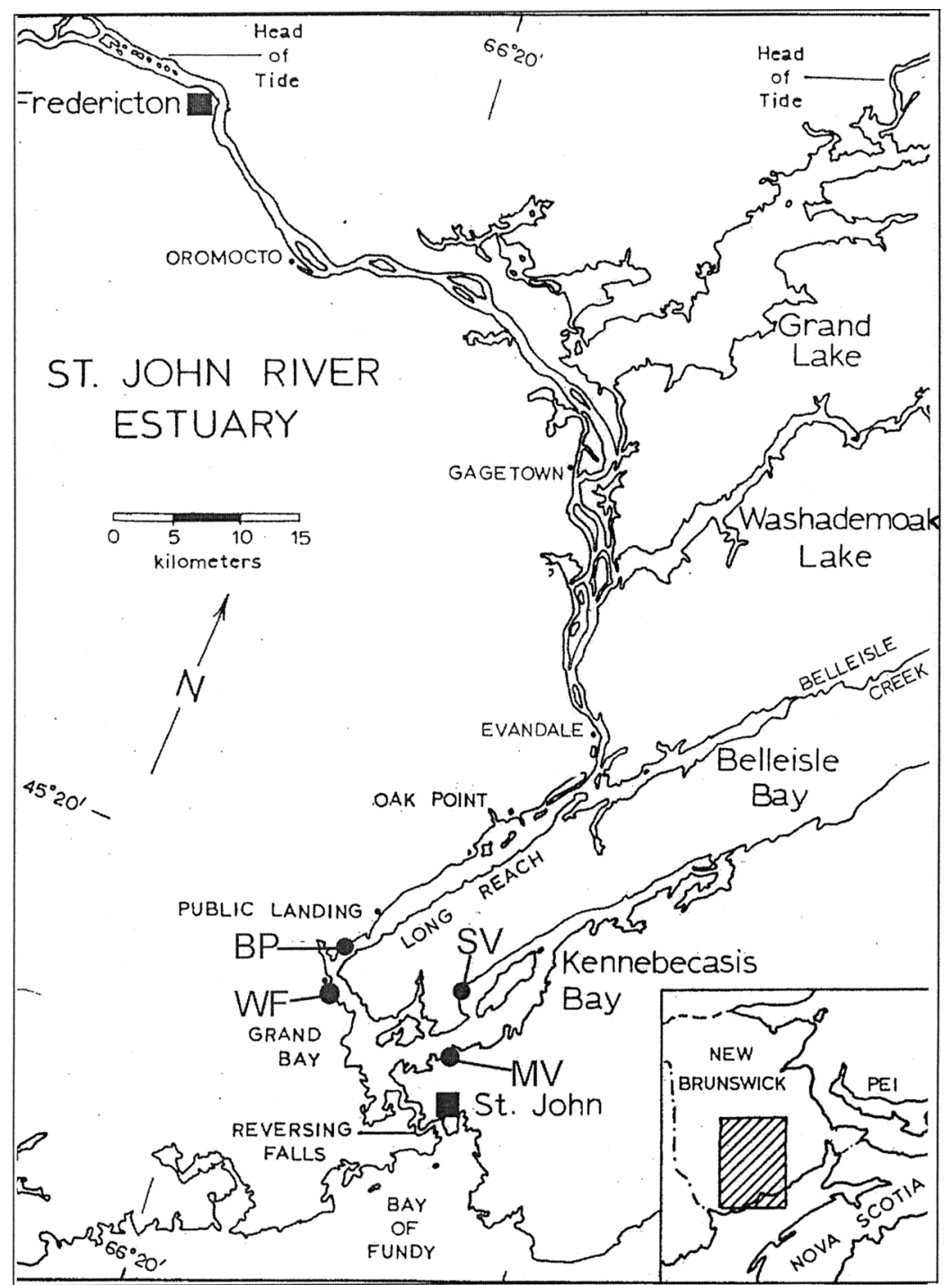

FIgure 1. Map of the Saint John River estuary, with the four study locations indicated. BP = Bell Point; WF = Westfield; $\mathrm{SV}=$ Summerville; $\mathrm{MV}=$ Millidgeville.

cacodylate buffer in seawater). Tissues were dehydrated in an ascending ethanol series, critical point dried using a Bio-Rad E3000 critical point drier with liquid $\mathrm{CO}_{2}$, and sputter coated with a Technics Hummer II sputter coater. Samples were viewed with a JEOL 5600LV Scanning Electron Microscope at 10kV.

Statistics were estimated with MINITAB 14, Microsoft Office Excel 2003, and SPSS 12. Graphs were plotted in Excel and SigmaPlot 9.0. Images were manipulated for size in Corel PhotoPaint 9 and labelled with CorelDraw 9.

\section{Results}

Water temperature, salinity and substrate were compared among all stations. For most of the study period water temperature ranged between 15 and $20^{\circ} \mathrm{C}$ (mean $19^{\circ} \mathrm{C}$ ), with the highest temperature of $28^{\circ} \mathrm{C}$ on 17 July 2004 (Mercer 2005). Water temperatures at the four stations were similar on each collection date (one-way ANOVA, $P=0.993$ ). Surface salinity ranged from $0.2 \mathrm{ppt}$ in spring to a maximum of $6.6 \mathrm{ppt}$ during mid-summer (Mercer 2005). However, mean salinity differed among the four stations (one-way ANOVA, 


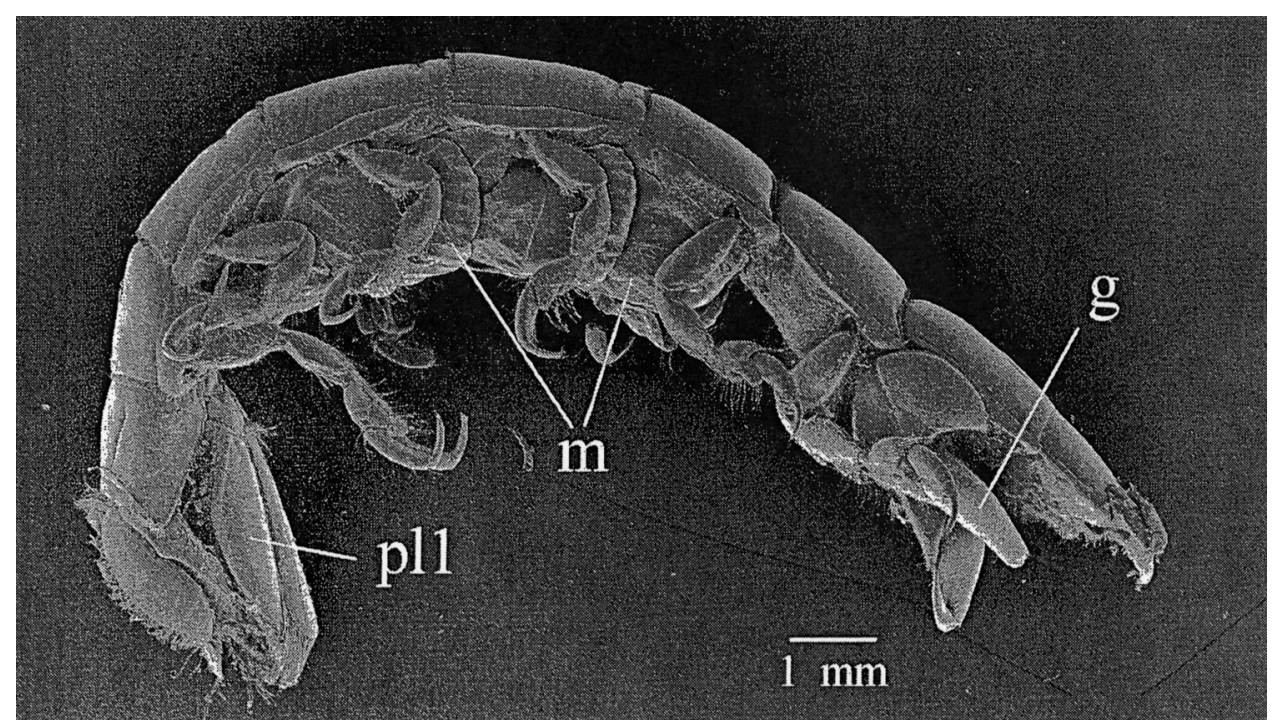

FIGURE 2. Scanning electron micrograph of a female Cyathura polita with marsupium, collected from the Saint John River during the summer of 2004. Symbols are: $\mathrm{g}=$ gnathopod, $\mathrm{m}=$ marsupium, $\mathrm{pl} 1=1^{\text {st }}$ pleopod.

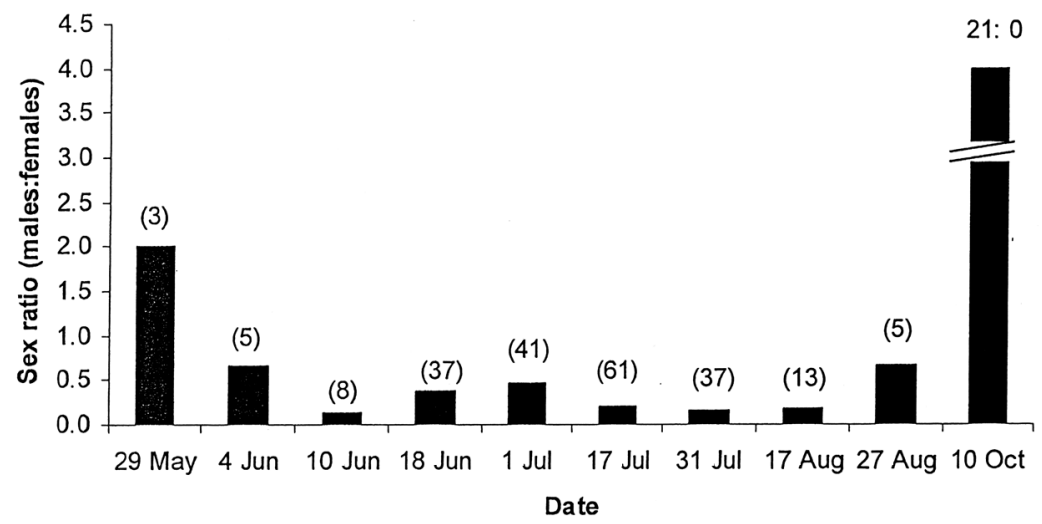

FIGURE 3. Male to female sex ratio of Cyathura polita during the study period in the Saint John River estuary. Data were pooled from four stations, and sample size $(n)$ is given in brackets above each column. On 10 October, most adult isopods collected were male, resulting in a different scale, thus the sex ratio is given above the bar.

$P<0.001)$. Mean salinities at Bell Point $(0.69 \pm 0.31$ ppt $)$ and Westfield $(1.5 \pm 0.86 \mathrm{ppt})$ were similar (Fisher's 95\% CI of $-0.35,0.78$ ), while Millidgeville $(4.7 \pm 1.3 \mathrm{ppt})$ and Summerville $(4.9 \pm 1.5 \mathrm{ppt})$ were comparable (Fisher's 95\% CI of -0.94, 0.19).

Sediment composition varied among the four study sites but all generally consisted of easily drained substrates (no anoxia; Mercer 2005). Bell Point had the highest gravel content of the four $(84.5 \%)$, with little sand $(15.1 \%)$ and hardly any silt $(0.4 \%)$. Westfield had the highest percentages of sand $(66.4 \%)$ and silt $(7.3 \%)$ and the least amount of gravel (26.3\%). Millidgeville contained more gravel $(55.9 \%)$ than sand $(43.5 \%)$ and very little silt $(0.6 \%)$. Summerville was similar to Millidgeville with abundant gravel (47.1\%) and sand $(51.5 \%)$ and little silt $(1.4 \%)$.

The sex ratio of $C$. polita varied during the study period, from a male:female ratio of 2:1 in May, declining to $0.5: 1$ in July, and increasing to 21:0 in October (Figure 3). In late spring, numbers of males exceeded females and large juveniles (probably maturing females) were present (Figure 4). From early June to the end of August, there were more females than males. Small, free-living juveniles, 2 to $3 \mathrm{~mm}$ in length, were first observed on 31 July 2004 numbers of presumably recently released from female marsupia. By the end of August, few distinguishable adults were collected at any station (Figure 4), but there were many 
large juveniles (probably adults without secondary sexual characteristics). In October, despite the rarity of males during late August, there was an abundance of relatively large males (Figure 3 ).

Over the entire study, $C$. polita in the Saint John River estuary were an average of $10.1 \pm 4.02 \mathrm{~mm}$ long, although the mean length varied among stations (Table 1). The mean length of all females collected was $13.8 \pm 2.14 \mathrm{~mm}(n=163)$ while males averaged $16.3 \pm 2.41 \mathrm{~mm}(n=68)$. Males were similar in length at all stations, as were females (Table 1; oneway ANOVA). Mean length of individuals collected from Bell Point and Millidgeville over the study period were similar, but isopods from both stations were significantly longer than those from Westfield and Summerville largely because the size of juveniles varied among stations (Table 1; one-way ANOVA). For three stations, mean juvenile length averaged $10.82 \pm 2.50 \mathrm{~mm}$ while juvenile cyathurans from Summerville were smaller $(8.60 \pm 2.49 \mathrm{~mm}$; Table 1$)$. Most $C$. polita collected at Summerville throughout the study period were juveniles. This fact was highlighted when comparing the size of juveniles at Summerville $(8.60 \pm 2.49 \mathrm{~mm}$ in length) to the size of all individuals collected at Summerville throughout the study $(8.71 \pm 2.92 \mathrm{~mm})$.

Seasonal changes in body length were estimated by comparing lengths of $C$. polita from each collection date, after sorting individuals by sex and reproductive stage (Figure 4). Since the physical characteristics were relatively similar among all stations growth data were pooled to assess life history. Females (with oostegites) were observed from 29 May to 27 August. Mature males were observed throughout the study, with peak abundance in late spring and early fall. Newly-released juveniles were first observed on 31 July and were abundant into the fall.

Cohort growth was estimated by comparing the mean length of each group of cyathurans at each collection date over the entire study period (Figure 5). Growth was estimated by extrapolating the mean length of each cohort in October back to the mean length of the next cohort in May. These estimates suggest that cyathurans from Saint John have a three-year life cycle, which spans four summer seasons. Young juveniles (Age 0 ) released from the marsupia at the end of July had a mean body length of $2.7 \pm 0.25 \mathrm{~mm}$ and averaged $7.5 \mathrm{~mm}$ by October. Young juveniles grew approximately $0.07 \mathrm{~mm} / \mathrm{day}$, the fastest of all groups, where growth was represented by: $\mathrm{y}=0.068 \mathrm{x}-11.9$ $\left(\mathrm{R}^{2}=0.99\right)$. The second cohort of juveniles (Age 1) had a mean length of $8.8 \pm 3.4 \mathrm{~mm}$ in May and grew approximately $0.02 \mathrm{~mm} /$ day were growth was represented by: $y=0.018 x+6.44\left(R^{2}=0.22\right)$, resulting in a mean length in October of $12.4 \pm 1.90 \mathrm{~mm}$. Mature females (Age 2) were $11.0 \mathrm{~mm}$ mean length in May, and grew slowly at a rate of $0.01 \mathrm{~mm} /$ day where growth was represented by: $y=0.009 x+11.3\left(R^{2}=0.05\right)$

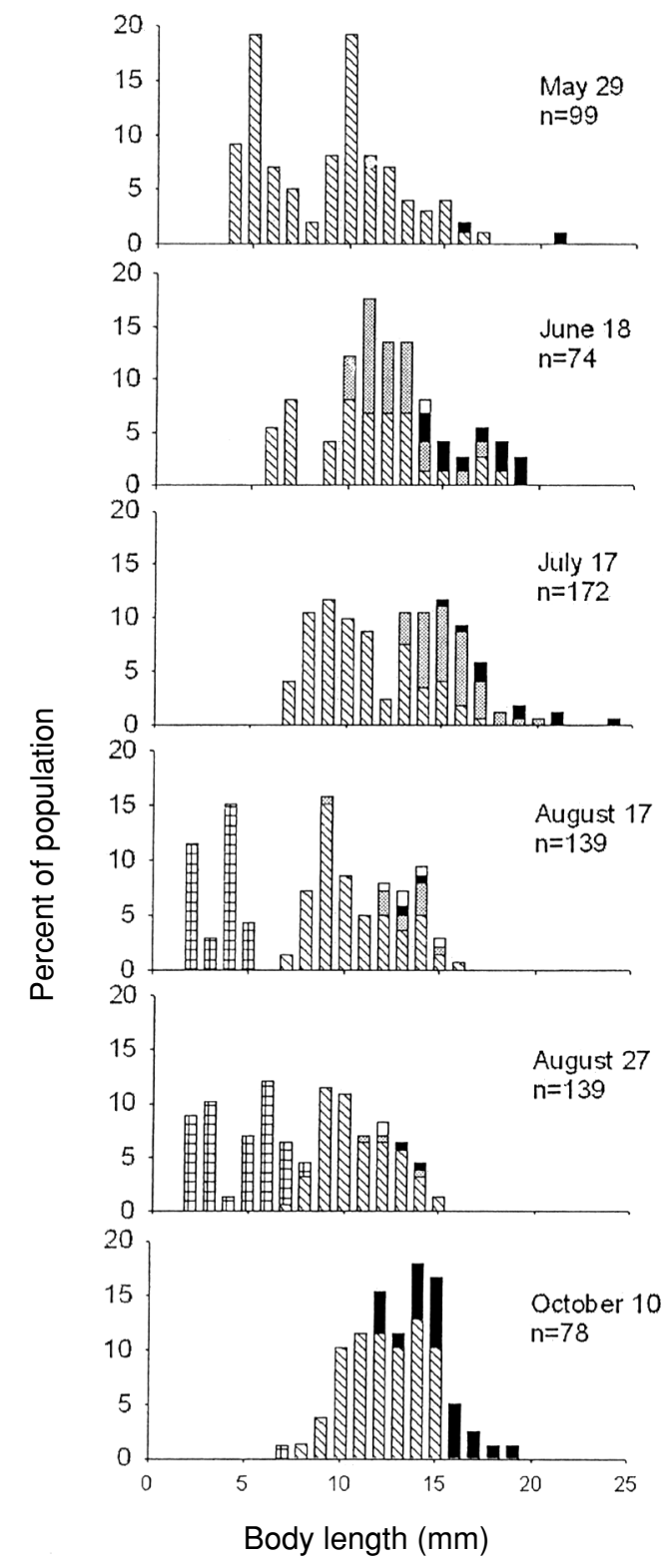

FIGURE 4. Size distribution of Cyathura polita in the Saint John River estuary for selected sampling dates during the summer of 2004, pooled from the four stations and grouped by sex and reproductive stage. New juveniles, horizontal bars; juveniles, cross-hatching; females, white; gravid female, stippled; males, black.

until they reached a mean length of $12.3 \pm 1.53 \mathrm{~mm}$ by the end of August. Females grew little during the summer; however, it was the reproductive period, suggesting resources were partitioned into reproduction, not growth. The size distribution of male cyathurans 
TABLE 1. Body lengths of Cyathura polita in the Saint John River estuary collected over the entire study period (29 May to 10 October 2004). Differences analyzed with a one-way ANOVA and a Scheffé post-hoc comparison among sites.

\begin{tabular}{|c|c|c|c|c|}
\hline Location & $\mathrm{N}$ & Mean length $\pm \mathrm{SD}(\mathrm{mm})$ & Minimum (mm) & Maximum (mm) \\
\hline \multicolumn{5}{|l|}{ All isopods } \\
\hline Bell Point & 247 & $11.2 \pm 3.06$ & 2.5 & 19.0 \\
\hline Westfield & 231 & $9.2 \pm 5.00$ & 2.0 & 21.0 \\
\hline Summerville & 297 & $8.7 \pm 2.90$ & 2.5 & 19.0 \\
\hline Millidgeville & 272 & $11.5 \pm 4.20$ & 2.5 & 24.0 \\
\hline \multicolumn{5}{|c|}{ one-way ANOVA df $=3,1046, \mathrm{f}=35.90, \mathrm{p}<0.000($ sites $\mathrm{BP}=\mathrm{MV}>\mathrm{WF}=\mathrm{SV})$} \\
\hline \multicolumn{5}{|l|}{ Males } \\
\hline Bell Point & 26 & $15.1 \pm 1.77$ & 12.0 & 18.0 \\
\hline Westfield & 11 & $17.3 \pm 2.57$ & 14.0 & 21.0 \\
\hline Summerville & 3 & $16.3 \pm 2.51$ & 14.0 & 19.0 \\
\hline Millidgeville & 28 & $16.9 \pm 2.54$ & 13.0 & 24.0 \\
\hline \multicolumn{5}{|c|}{ one-way ANOVA $\mathrm{df}=3,67, \mathrm{f}=3.633 \mathrm{~ns}$} \\
\hline \multicolumn{5}{|l|}{ Females } \\
\hline Bell Point & 50 & $13.4 \pm 1.87$ & 9.0 & 19.0 \\
\hline Westfield & 34 & $14.2 \pm 2.38$ & 8.0 & 20.0 \\
\hline Summerville & 16 & $12.7 \pm 2.79$ & 9.0 & 18.0 \\
\hline Millidgeville & 63 & $14.1 \pm 1.91$ & 9.0 & 17.0 \\
\hline \multicolumn{5}{|c|}{ one-way ANOVA $\mathrm{df}=3,162, \mathrm{f}=2.75 \mathrm{~ns}$} \\
\hline \multicolumn{5}{|l|}{ Juveniles } \\
\hline Bell Point & 136 & $10.6 \pm 2.01$ & 6.0 & 15.0 \\
\hline Westfield & 96 & $11.4 \pm 2.69$ & 6.0 & 18.0 \\
\hline Summerville & 262 & $8.6 \pm 2.49$ & 4.0 & 16.0 \\
\hline Millidgeville & 149 & $10.7 \pm 2.73$ & 7.0 & 17.0 \\
\hline \multicolumn{5}{|c|}{ one-way ANOVA df $=3,642, \mathrm{f}=43.75, P<0.000($ sites $\mathrm{BP}=\mathrm{MV}=\mathrm{WF}>\mathrm{SV})$} \\
\hline
\end{tabular}

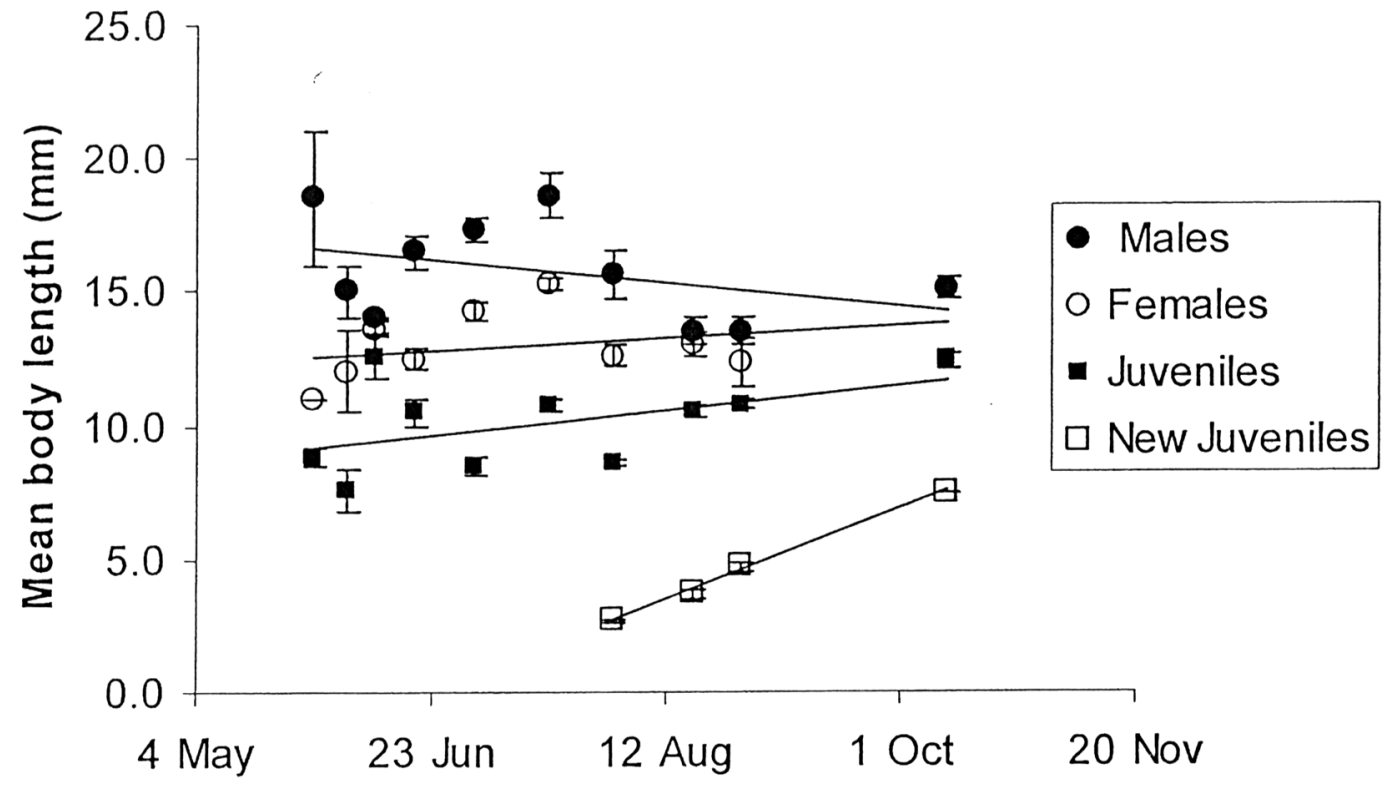

\section{Date}

FIGURE 5. Mean length of Cyathura polita from the Saint John River estuary pooled from all stations at each sampling interval during the summer of 2004 and grouped by sex and reproductive stage. Vertical bars are standard deviations. 
was very different from that of juveniles and females. Males (Age 3) were largest at the end of May (mean length $18.5 \pm 3.54 \mathrm{~mm}$ ), but smaller in October (mean length $15.1 \pm 1.95 \mathrm{~mm}$ ). A bi-modal size distribution during the growing season suggests the die-off of larger and older males in early summer, and the addition of new, smaller males in the fall as females underwent protogynic sex change or some large juveniles matured as males.

Other studies noted latitudinal variation in body length of $C$. polita, with individuals from more northern populations being generally larger than in southern populations. However, environmental conditions, such as the type of substrate or depth of water, may also strongly affect body size (Burbanck and Burbanck 1979). To assess whether cyathurans from Saint John followed this latitudinal trend, their mean body lengths were compared to values reported in the literature (Table 2). Females pooled from all stations had a mean length of $13.8 \pm 2.14 \mathrm{~mm}$ (maximum: $20.0 \mathrm{~mm}$ ), and males had a mean length of $16.3 \pm 2.41 \mathrm{~mm}$ (maximum: $24.0 \mathrm{~mm}$ ). These lengths were similar to cyathurans populations studied north of North Carolina, although none collected at Saint John were as large as the maximum length $(27 \mathrm{~mm})$ of the individuals collected from Chewonki Creek, Maine (Burbanck 1959). The individuals collected in the Saint John estuary differed markedly from southern populations such as Georgia and Florida: the largest male collected at St. Mark's, Florida, was only $1.8 \mathrm{~mm}$ larger than the smallest male collected in the Saint John (Kruczynski and Subrahmanyam 1978).

Broods were examined from 72 females, pooled from all four stations. Fecundity ranged from 16 to 98 embryos per brood, with a mean of $53.2 \pm 18.9$ embryos (Table 3). Abundant gravid females with embryos were first observed on 1 July. All of these broods contained early embryos (Class 1), with a mean length of $0.45 \pm 0.06 \mathrm{~mm}$. Two weeks later, more than half of the broods contained elongated Class 2 and 3 embryos, while the remainder contained Class 1 embryos. By the end of July, $50 \%$ of broods contained Class 4 young that had hatched out of their vitelline membranes but were still developing within the marsupia. By mid-August, only six gravid females were found: two had very large Class 1 broods and two had late-stage Class 4 broods. Within the marsupium, embryos grew from a mean length of $0.49 \pm 0.08 \mathrm{~mm}$ as Class 1 embryos to a mean length of $2.07 \pm 0.16 \mathrm{~mm}$ when they were ready to be released as juveniles. Class 2 and 3 embryos had a mean length of $1.05 \pm 0.15 \mathrm{~mm}$ and $1.12 \pm 0.19 \mathrm{~mm}$, respectively (Table 3 ).

There was no correlation between female length and fecundity $\left(\mathrm{R}^{2}=0.01\right)$. There was also no effect of embryos/brood on embryo size $\left(\mathrm{R}^{2}=0.01\right)$ and little mortality within broods during development (Mercer 2005). Within-brood survivorship was $96.4 \%$ with only a slight decrease observed in mean embryos/brood when compared between Class 1 (57.9 \pm 18.77 embryos/brood) and Class 4 broods (55.8 \pm 19.64 embryos/ brood).

\section{Discussion}

Cyathura polita from the Saint John River estuary exhibits several modifications in life history associated with its northern distribution. In particular, this population exhibits a longer life span, a shorter and later reproductive season, and produces larger adults with higher fecundity, in comparison to southern populations. Additionally, our data suggest that protogynic hermaphroditism occurs, as found in some other populations (Burbanck and Burbanck 1974).

In the Saint John River estuary, $C$. polita exhibits a three-year life cycle. Juveniles are released during July and August (Age 0) and, after little growth during the winter, remain immature the following summer (Age 1). Over the course of their second winter, juveniles develop into mature females (Age 2), which reproduce the following summer. Then, based on our length and sex ratio data, females either die or become males (Age 3) during the late summer-fall, and reproduce as males during their final summer of life. The result is a three-year life cycle, which spans four summers. In contrast, $C$. polita from southern populations have shorter life cycles. For example, in St. Mark's, Florida, C. polita are mature one year after hatching and reproduce throughout their second summer, suggesting a life cycle of less than two years (Kruczynski and Subrahmanyam 1978), while on southern Cape Cod, $C$. polita reproduce in their second, and sometimes third, summer, suggesting a two-year life cycle (Burbanck 1962a; Burbanck and Burbanck 1979).

Latitudinal changes in the duration and timing of reproduction are also evident. Cyathura polita reproduce from April to August in St. Mark's, Florida (Kruczynski and Subrahmanyam 1978), from June to July at Cape Cod, Massachusetts (Burbanck 1962a) and July and August in the Saint John estuary (present study). Although the breeding season is short and relatively simultaneous in the Saint John population, females were found with broods at different stages of embryonic development throughout the brooding period, especially in mid- to late-July.

The longer life cycle and delayed reproduction in northern cyathurans probably occur because of a shorter growing season. The population in the Saint John lives in water that averages $19.0^{\circ} \mathrm{C}$ during summer, but shallow water temperatures decline to near $0^{\circ} \mathrm{C}$ from December until April (Metcalfe et al. 1976). The result is limited opportunity for growth and reproduction in warmer waters, resulting in delayed maturation. In contrast, cyathurans from Florida live at temperatures ranging between $13.8^{\circ}$ and $33^{\circ} \mathrm{C}$, and above $20^{\circ} \mathrm{C}$ for ten months of the year (Kruczynski and Subrahmanyam 1978). Previous studies suggest that rapid growth in cyathurans occurs only during periods 
TABLE 2. Summary of body lengths for $C$. polita reported in the literature, as means \pm S.D. or range, depending on the source.

\begin{tabular}{|c|c|c|}
\hline Location of study & Body length (mm) & Author(s) \\
\hline Saint John, New Brunswick & $\begin{array}{cc}\sigma^{7} & 16.3 \pm 0.29 \\
\text { ○ } 13.8 \pm 0.17\end{array}$ & present study \\
\hline Marsh River, Maine & $\begin{array}{l}\text { ơ } 14-21 \\
\text { ㅇ } 14-19\end{array}$ & Haefner et al. 1969 \\
\hline Marshfield, Massachusetts & $13.3 \pm 0.33$ & Frankenberg 1962 \\
\hline Sapelo Island, Georgia & $9.3 \pm 0.64$ & Frankenberg 1962 \\
\hline St. Mark's, Florida & $\begin{array}{l}\text { ơ } 7.3-13.8 \\
\text { ㅇ } 8.3-13.0\end{array}$ & Krucsynski and Subrahmanyam 1978 \\
\hline
\end{tabular}

TABLE 3. Fecundity and mean embryo length of Cyathura polita in the Saint John River estuary. Embryos were grouped by class of development where: Class 1 embryos were round and contained in two membranes, the chorion and vitelline, Class 2 embryos were elongated and differentiated into three body regions (head, thorax and abdomen), Class 3 embryos were within vitelline membrane but had differentiated appendages, Class 4 embryos were hatched from the vitelline membrane (Mercer et al. in press).

\begin{tabular}{lccccc}
\hline \hline $\begin{array}{l}\text { Date } \\
\text { collected }\end{array}$ & $\begin{array}{c}\text { Class of } \\
\text { development }\end{array}$ & $\begin{array}{c}\text { Number of } \\
\text { gravid females }\end{array}$ & $\begin{array}{c}\text { Fecundity } \\
\text { Mean } \pm \text { SD }\end{array}$ & $\begin{array}{c}\text { Total number } \\
\text { of embryos }\end{array}$ & $\begin{array}{c}\text { Embryo length (mm) } \\
\text { Mean } \pm \text { SD }\end{array}$ \\
\hline 1 July & 1 & 15 & $52.8 \pm 22.48$ & 956 & $0.45 \pm 0.06$ \\
17 July & 1 & 13 & $59.4 \pm 11.08$ & 658 & $0.52 \pm 0.09$ \\
& 2 & 14 & $47.0 \pm 18.88$ & 630 & $1.05 \pm 0.15$ \\
31 July & 3 & 7 & $38.3 \pm 14.21$ & 207 & $1.10 \pm 0.11$ \\
& 1 & 3 & $52.0 \pm 22.61$ & 181 & $0.52 \pm 0.01$ \\
& 2 & 1 & 23 & 341 & $1.03 \pm 0.11$ \\
17 August & 3 & 11 & $50.5 \pm 15.34$ & 540 & $1.14 \pm 0.24$ \\
& 4 & 2 & $91.3 \pm 24.18$ & 180 & $2.06 \pm 0.16$ \\
& 1 & 1 & 4 & & $0.59 \pm 0.07$ \\
& 2 & 1 & 57 & 67 & $1.07 \pm 0.15$ \\
& 3 & 2 & $33.5 \pm 41.72$ & $6.13 \pm 07$ \\
\hline \hline
\end{tabular}

of higher water temperature, and that growth ceases when waters cool (Olafsson and Persson 1986). The two-year life cycle described for Cape Cod may be more similar to the southern populations, perhaps because the southern side of Cape Cod, where the study was conducted, is more Virginian in nature than Boreal (Gosner 1971).

Cyathura carinata, common along the coast of Europe, exhibits a similar cline in life history traits. Studies of $C$. carinata in Portugal have suggested relatively short life cycles of 19 (Cruz et al. 2003) or 18 to 22 months (Marques et al. 1994). However, threeyear life cycles are reported for $C$. carinata populations in more northern locations such as Poland (Jazdzewski 1969), Sweden (Olafsson and Persson 1986) and England (Bamber 1985). Olafsson and Persson (1986) suggest that $C$. carinata populations in Sweden require two years before juveniles are able to mature and reproduce, in contrast to southern populations, which are able to reproduce after one year. Bamber (1985) suggests that a longer life cycle is necessary in northern populations as the isopods cannot grow during the winter; whereas southern populations are able to grow continuously and attain mature size sooner.
Cyathura polita in the Saint John River estuary appears to exhibit protogynic hermaphroditism. Sequential hermaphroditism is rare in marine peracaridans, although relatively common in terrestrial and parasitic species (Johnson et al. 2001). Brooks et al. (1994) report that of the approximately 60 species of crustaceans known to be sequential hermaphrodites, only a few are protogynous, including three species of Cyathura, three other isopods and five species of tanaids. Evidence for protogyny from the present study includes sex ratio and adult size. Males were abundant in the population in May and again in October, but rare during summer when the majority of adults were females. Also, males in the fall were similar in length to spent females at the end of the summer (approximately 15 and $12 \mathrm{~mm}$ in length, respectively), while most large juveniles were smaller (approximately $10 \mathrm{~mm}$ in length). Males continue to grow during the fall and reach a length of approximately $18 \mathrm{~mm}$ in the spring of their final year. These observations support a model of protogynic hermaphroditism, whereby mature females become reproductive in early summer of their second year (i.e., third summer) and release juveniles during late July and August. After the release of young, 
females molt, change sex, and function as mature males in their fourth spring and summer, before death.

The hypothesis that $C$. polita in the Saint John River are protogynic hermaphrodites is consistent with evidence of sex change reported from other populations under both laboratory (Burbanck and Burbanck 1974) and field conditions (Kruczynski and Subrahmanyam 1978). While it is possible that males migrate to other areas of the estuary after reproducing and return to shallow waters in the fall, previous work suggests that mostly immature cyathurans occur in the deeper waters of this estuary, while reproductive adults are in shallower water (Gillis 1974; Burbanck et al. 1979). Burbanck and Burbanck $(1974,1979)$ have reported that some primary males can develop directly from juveniles, which may account for some of the variation in sex ratios and body lengths observed here.

As hypothesized by Bamber (1985), it would be advantageous for male cyathurans to be larger than females to reduce their chances of mortality. Males are able to mate with more than one female, but need to leave their burrows in order to mate, thus they are at a greater risk of predation. Females do not need to expose themselves to that risk, and thus may mature at a smaller size. Warner (1988) additionally suggested that it would be advantageous to become male at a larger size if there is competition among males for females.

With a few exceptions, the development of embryos collected at Saint John was synchronized within a brood, which agrees with observations on cyathurans by Stromberg (1972) and Bamber (1985). Our observations suggest that the brooding period for females in the Saint John River estuary lasts from 30 to 45 days. Class 1 embryos were first observed in marsupia on 1 July. The first hatched embryos (Class 4) were observed on 31 July, which corresponds with the first appearance of new juveniles. While comparable observations are not available for more southern populations of this species, a 30 to 45 day brooding period may be typical for this genus. Olafsson and Persson (1986) found that a $C$. carinata population on the southern coast of Sweden had a three to four week brooding period, while others studying $C$. carinata in Portugal determined embryonic development to also last 30 to 45 days (Cruz et al. 2003).

Brood size is not widely reported for $C$. polita, however broods collected from Saint John were much larger $(53.2 \pm 18.9$ embryos/brood $)$ than broods from Florida (mean: 14 embryos/ brood, range 2-32; Kruczynski and Subrahmanyam 1978). A similar south-north cline is known in the European C. carinata. Bamber (1985) found that $C$. carinata females in England carry a mean of 29.8 embryos/brood (range 14-45), while $C$. carinata females in Sweden averaged $42 \pm 12$ embryos/ brood (Olafsson and Persson 1986). The large brood size in Saint John C. polita is likely a function of increased female size because of greater age (3 vs. 2 years). Larger females would likely have larger marsupia and therefore may be able to carry more embryos.

Cyathura polita at the northernmost extent of its range exhibits several modifications in life history compared to more southern North American populations. These modifications are similar to those observed among European $C$. carinata populations. Our results support the existence of a latitudinal cline in life history traits in Cyathura, with implications for life span, size and fecundity. Plasticity in reproduction, coupled with protogynic hermaphroditism, makes $C$. polita an excellent model for studies of the effects of the environment on life history traits.

Cyathura polita is an important indicator of estuarine health (Burbanck and Burbanck 1979) and since the Saint John River estuary has one of the few populations in Canada there are compelling reasons to understand its life history and population size. We suggest a more comprehensive knowledge of the biology of this isopod in the Saint John could assist both with pollution monitoring and with further the distinction of the Saint John estuary as a distinct ecosystem in Canada. Future study of the Saint John cyathurans should be undertaken to verify the 3-year life cycle with sampling throughout the year and to define its estuarine distribution and abundance. Cyathura polita occurs as far inland in the Saint John estuary as Washademoak Lake (Figure 1; Burbanck et al. 1979) and it is a common prey of the Shortnose Sturgeon (Acipenser brevirostrum) another southern species that is endemic to this estuary in Canada (Dadswell 1979).

\section{Acknowledgments}

This project was supported by NSERC (Natural Sciences and Engineering Research Council of Canada) through a grant to G. Gibson. The authors are grateful to Acadia University for use of equipment; D. MacDonald and G. Cheeseman of the Acadia Centre for Microstructural Analysis; T. Avery for reviews and corrections, Y. Zhang for statistics assistance (Acadia University Statistical Consulting Centre), and R. Mercer and C. Mercer for assistance with field work.

\section{Literature Cited}

Bamber, R. N. 1985. The autecology of Cyathura carinata (Crustacea: Isopoda) in a cooling water discharge lagoon. Journal of the Marine Biological Association U.K. 65: 181-194.

Bousfield, E.L. 1962. Studies on littoral marine arthropods from the Bay of Fundy region. National Museum of Canada Bulletin 183: 42-62.

Brooks, H.J., T. A. Rawlings, and R. W. Davies. 1994. Protogynous sex change in the intertidal isopod Gnorimosphaeroma oregonense (Crustacea: Isopoda). Biological Bulletin 187: 99-111.

Burbanck, W. D. 1959. The distribution of the estuarine isopod, Cyathura sp., along the eastern coast of the United States. Ecology 40: 507-511. 
Burbanck, W. D. 1962a. An ecological study of the distribution of the isopod Cyathura polita (Stimpson) from brackish waters of Cape Cod, Massachusetts. American Midland Naturalist 67: 449-476.

Burbanck, W. D. 1962b. Further observations on the biotope of the estuarine isopod, Cyathura polita. Ecology 43: 719-722.

Burbanck, M. P., and W. D. Burbanck. 1974. Sex reversal of female Cyathura polita (Stimpson, 1855) (Isopoda, Anthuridae). Crustaceana 26: 110-112.

Burbanck, W.D, and M. P. Burbanck. 1979. Cyathura (Arthropoda: Crustacea: Isopoda: Anthuridae). Pages 293323 in Pollution Ecology of Estuarine Invertebrates. Edited by C. W. Hart, Jr. and S. L. H. Fuller. Academic Press, New York.

Burbanck, M. P., W. D. Burbanck, M. J. Dadswell, and G. F. Gillis. 1979. Occurrence and biology of Cyathura polita (Stimpson) (Isopoda, Anthuridae) in Canada. Crustaceana 37: 31-38.

Carter, J. C. H., and M. J. Dadswell. 1983. Seasonal and spatial distribution of planktonic crustacea in the lower Saint John River, a multi-basin estuary in New Brunswick, Canada. Estuaries 6: 142-153.

Cruz, S., J. C. Marques, S. Gamito, and I. Martins. 2003. Autecology of the isopod, Cyathura carinata (Kroyer, 1847 ) in the Rio Formosa (Algarve, Portugal). Crustaceana 76: 781-802.

Dadswell, M. J. 1979. Biology and population characteristics of the shortnose sturgeon Acipenser brevirostrum LeSueur, 1818 (Osteichthyes: Acipenseridae), in the Saint John River estuary, New Brunswick, Canada. Canadian Journal of Zoology 58: 2186-2210.

Frankenberg, D. 1962. A comparison of the physiology and ecology of the estuarine isopod Cyathura polita (Stimpson) in Massachusetts and Georgia. Unpublished Ph.D. thesis, Emory University, Georgia.

Gillis, G. F. 1974. An ecological survey in the Saint John estuary. Huntsman Marine Laboratory, St. John River Basin Report 15: 1-64.

Gorham, S. W. 1965. Notes on fishes from the Browns Flat area, Kings County, New Brunswick. Canadian FieldNaturalist 79: 137-142.

Gosner, K. L. 1971. Guide to identification of marine and estuarine invertebrates. Wiley-Interscience, New York

Haefner, J., P. A. M. Mazurkiewicz, and W. D. Burbanck. 1969. Range extension of the North American estuarine isopod crustacean, Cyathura polita (Stimpson, 1855). Crustaceana, 17: 314-317.
Jazdzewski, K. 1969. Biology of two hermaphroditic Crustacea, Cyathura carinata (Kroyer) (Isopoda) and Heterotanais oerstedi (Kroyer) (Tanaidacea) in waters of the Polish Baltic Sea. Zoologica Poloniae 19: 5-25.

Johnson, W. S., M. Stevens, and L. Watling. 2001. Reproduction and development of marine peracaridans. Advances in Marine Biology 39: 105-260.

Kruczynski, W. L., and C. B. Subrahmanyam. 1978. Distribution and breeding cycle of Cyathura polita (Isopoda: Anthuridae) in a Juncus roemerianus marsh of northern Florida. Estuaries 1: 93-100.

Marques, J. C., I. Martins, C. Teles-Ferreira, and S. Cruz. 1994. Populations dynamics, life history, and production of Cyathura carinata (Kroyer) (Isopoda: Anthuridae) in the Mondego Estuary, Portugal. Journal of Crustacean Biology 14: 258-272.

Mercer, S. C. 2005. Life history strategy and morphogenesis of Cyathura polita (Stimpson, 1855) in the Saint John River, New Brunswick, Canada. Unpublished Honours thesis, Acadia University, Wolfville, Nova Scotia.

Mercer, S. C., M. J. Dadswell, and G. D. Gibson. In press. Morphogenesis of embryos and manca in the direct developing estuarine isopod, Cyathura polita (Anthuridae). Journal of Invertebrate Biology.

Metcalfe, C. D., M. J. Dadswell, G. F. Gillis, and M. L. H. Thomas. 1976. Physical, chemical, and biological parameters of the Saint John River Estuary, New Brunswick, Canada. Fisheries and Marine Service, Research and Development Technical Report 686.

Miall, A. D. 2000. Principles of sedimentary basin analysis. Springer-Verlag, New York.

Olafsson, E. B., and L.-E. Persson. 1986. Distribution, life cycle and demography in a brackish water population of the isopod Cyathura carinata (Kroyer) (Crustacea). Estuarine, Coastal and Shelf Science 23: 673-687.

Stromberg, J-O. 1972. Cyathura polita (Crustacea, Isopoda), some embryological notes. Bulletin of Marine Science 22: 463-482.

Rogers, H. M. 1936. The estuary of the Saint John River. Its physiology, ecology, and fisheries. Unpublished MA thesis, University of Toronto, Toronto, Ontario.

Trites, R. W. 1960. An oceanographic and biological reconnaissance of Kennebecasis Bay and the Saint John estuary. Journal of the Fisheries Research Board of Canada 17: 377-408.

Warner, R. R. 1988. Sex change and the size-advantage model. Trends in Ecology and Evolution 3: 133-136.

Received 8 August 2006

Accepted 30 May 2008 